\begin{tabular}{lrr}
\hline Volume 22 & Nomor 1, Januari 2021 & Halaman 41-48 \\
URL: https://jurnal.unej.ac.id/index.php/SEMIOTIKA/index & E-ISSN: 2599-3429 & P-ISSN: 1411-5948 \\
\hline
\end{tabular}

\title{
ANALISIS TINDAK ILOKUSI YANG DILAKUKAN OLEH GSD DALAM VIDEO KENAPA KITA MEMBENCI?
}

\author{
AN ANALYSIS OF ILLOCUTIONARY ACTS IN GSD'S \\ VIDEO ENTITLED KENAPA KITA MEMBENCI?
}

\author{
Suci Nurul Afidah ${ }^{1 *}$, Asep Purwo Yudi Utomo ${ }^{2}$ \\ ${ }^{1,2}$ Fakultas Bahasa dan Seni, Universitas Negeri Semarang \\ *Corresponding Author: suciafidah@students.unnes.ac.id \\ Informasi Artikel: \\ Dikirim: 13/6/2020; Direvisi: 20/10/2020; Diterima: 25/12/2021
}

\begin{abstract}
In language, apart from utterances, there is also action. This research is conducted to describe the illocutionary speech acts performed by GSD in one of the videos on the YouTube channel entitled Kenapa Kita Membenci? The method used in this research is a descriptive qualitative method. The data in this study are in the form of illocutionary speech acts spoken by GSD in one of the videos on his YouTube channel. The source of data in this study is the narrative presented by GSD in the video. The data collection technique uses the observation technique. The research data were transcribed, classified, verified, and concluded inductively. The results showed that in the video, there were various kinds of illocutionary speech acts. The illocutionary speech acts performed are assertive, directive, and expressive. GSD does not do commissive and declarative illocutionary speech acts.
\end{abstract}

Keywords: illocutionary, speaker, speech act, speech

Abstrak

Bahasa, di samping ujaran, adalah tindakan. Penelitian ini bertujuan mendeskripsikan tindak tutur ilokusi yang dilakukan oleh GSD pada salah satu unggahan video di Kanal YouTube berjudul Kenapa Kita Membenci? Metode yang digunakan dalam penelitian ini adalah metode deskriptif kualitatif. Data dalam penelitian ini berupa tindak tutur ilokusi yang dituturkan oleh GSD dalam salah satu video di Kanal Youtube miliknya. Sumber data dalam penelitian ini adalah narasi yang disampaikan oleh GSD dalam video tersebut. Teknik pengumpulan data menggunakan teknik simak. Data penelitian ditranskripsi, diklasifikasi, diverifikasi, dan disimpulkan secara induktif. Hasil penelitian menunjukkan bahwa dalam videonya, melakukan tindak tutur ilokusi bermacam-macam. Tindak tutur ilokusi yang dilakukan, meliputi: tindak tutur ilokusi asertif, tindak tutur ilokusi direktif, dan tindak tutur ilokusi ekspresif. Tindak tutur ilokusi yang tidak dilakukan oleh GSD adalah tindak tutur ilokusi komisif dan tindak tutur ilokusi deklaratif.

Kata kunci: ilokusi, penutur, tindak tutur, tuturan 


\section{PENDAHULUAN}

Pragmatik merupakan salah satu cabang ilmu linguistik yang masih tergolong baru namun mengalami perkembangan yang cukup pesat. Perkembangan pragmatik ini disebabkan karena semakin tingginya tingkat kesadaran para ahli bahasa terhadap pemahaman pragmatik, yakni bagaimana bahasa itu digunakan dalam komunikasi. Para ahli bahasa menyadari bahwa perkembangan bahasa selalu mengikuti perkembangan pola pikir manusia, teknologi, kebudayaan, dan pendidikan (Rohmadi, 2017:1).

Studi bahasa dalam pragmatik selalui terkait dan terikat dengan konteks dan juga koteks. Konteks memiliki peranan kuat dalam menentukan maksud penutur dalam berinteraksi dengan lawan tutur. Pragmatik dapat dimanfaatkan setiap penutur untuk memahami maksud lawan tutur. Sebuah tuturan dapat digunakan untuk menyampaikan beberapa maksud atau sebaliknya. Hal ini bergantung pada konteks yang melingkupi tuturan itu.

Tindak tutur adalah gejala individual yang bersifat psikologis dan keberlangsungannya ditentukan oleh kemampuan bahasa si penutur dalam menghadapi situasi tertentu (Chaer dan Agustina, 1995:65). Menurut Searle (dalam Rohmadi, 2017:32), secara pragmatis setidaknya ada tiga jenis tindakan yang dapat diwujudkan oleh seorang penutur, yakni tindak lokusi (locutionary act), tindak ilokusi (illocutionary act), dan tindak perlokusi (perlocutionary act).

Tindak tutur ilokusi merupakan tindak tutur yang selain berfungsi untuk mengatakan atau menginformasikan sesuatu juga dipergunakan untuk melakukan sesuatu. Tindak ilokusi sangat sulit untuk diidentifikasi karena terlebih dahulu harus mempertimbangkan siapa penutur dan lawan tuturnya (Rohmadi, 2017:33).

Tindak ilokusi dapat diklasifikasikan menjadi empat jenis, sesuai dengan hubungan fungsi-fungsi tersebut dengan tujuan sosial berupa pemeliharaan perilaku yang sopan dan terhormat, yaitu sebagai berikut. Pertama, adalah ilokusi kompetitif. Tujuan ilokusi ini adalah bersaing dengan tujuan sosial, seperti memerintah, meminta, menuntut, mengemis. Yang kedua, adalah ilokusi menyenangkan. Tujuan ilokusi ini sejalan dengan tujuan sosial, misalnya menawarkan, mengajak atau mengundang, menyapa, mengucapkan selamat, mengucapkan terima kasih. Ketiga, adalah ilokusi bekerja sama. Tujuan ilokusi ini tidak menghiraukan tujuan sosial, misalnya menyatakan, melapor, mengumumkan, mengajarkan. Keempat, adalah ilokusi bertentangan. Tujuan ilokusi ini bertentangan dengan tujuan sosial, misalnya mengancam, menuduh, menyumpahi, memarahi (Leech, 1993:162).

Searle (dalam Rohmadi, 2017:33) membagi tindak tutur ilokusi menjadi lima kategori, yaitu sebagai berikut.

1) Tindak tutur ilokusi asertif. Dalam tindak tutur ini informasi terikat pada kebenaran proposisi yang diungkapkan, misalnya, menyatakan, mengusulkan, mengeluh, mengemukakan pendapat, melaporkan.

2) Tindak tutur ilokusi direktif. Tindak tutur ini bertujuan menghasilkan suatu efek berupa tindakan yang dilakukan oleh penutur, misalnya, memesan, memerintah, memohon, menuntut, memberi nasihat.

3) Tindak tutur ilokusi komisif. Dalam tindak tutur ini informasi terikat pada suatu tindakan di masa depan, misalnya menjanjikan, menawarkan. 
4) Tindak tutur ilokusi ekspresif. Ilokusi ini berfungsi untuk mengungkapkan atau mengutarakan sikap psikologis penutur terhadap keadaan yang tersirat dalam ilokusi, misalnya, mengucapkan terima kasih, mengucapkan selamat, memberi maaf, mengecam, memuji, dan sebagainya.

5) Tindak tutur ilokusi deklarasi. Ilokusi ini akan mengakibatkan adanya kesesuaian antara isi proposisi dengan realitas, misalnya mengundurkan diri, memecat, membaptis, memberi nama, dan sebagainya (Leech, 1993:164).

Dalam penelitian ini, peneliti memilih salah satu video dalam kanal YouTube salah seorang influencer, yaitu Gita Savitri Devi-selanjutnya disebut GSD—sebagai objek penelitian. GSD kerap membagikan pemikiran-pemikiran serta argumennya terhadap suatu isu yang sedang berkembang, baik itu di Indonesia atau di dunia. Dalam menyampaikan pendapatnya, GSD menggunakan bahasa yang ringan dan santai, sehingga mudah dipahami oleh orang awam dan terkesan tidak menggurui.

Dalam kanal YouTube-nya, GSD mempunyai dua segmen video yang dalam segmen itu GSD menyampaikan pendapat atau argumennya. Segmen yang pertama yaitu Beropini, dalam segmen ini, GSD membahas suatu isu yang sedang marak diperbincangkan ataupun isu yang menjadi keresahannya secara pribadi. Video jenis ini berdurasi antara 5 sampai 20 menit. Sebelum menyampaikan pendapatnya, GSD juga memaparkan fakta-fakta atau data-data terkait isu yang sedang dibahas.

Segmen video yang kedua adalah Pagi-Pagi with Paul and Gita. Dalam segmen ini, GSD lebih fokus membahas isu yang sedang hangat-hangatnya diperbincangkan. Dalam segmen ini, dia ditemani oleh sang suami Paul. Dalam video ini mereka berbagi pemikiran atau pendapat terkait isu-isu yang sedang hangat diperbincangkan. Segmen ini tidak hanya fokus pada satu isu saja, sehingga durasi videonya juga lebih panjang, sekitar 30 sampai 50 menit, terlebih konsep segmen ini tidak adanya pemotongan video, sehingga semua yang mereka katakan selama proses pembuatan video terekam.

Dalam penelitian kali ini, peneliti memilih segmen video Beropini dengan judul "Kenapa Kita Membenci?_yang selanjutnya disebut KKM—yaitu Beropini pada episode 46". Dalam video ini, Gita mengangkat tema tentang mengapa seseorang itu bisa membenci orang lain. Dalam video ini, GSD memaparkan beberapa faktor mengapa seseorang dapat membenci dan bagaimana caranya agar kita tidak mudah membenci orang lain.

\section{METODE}

Metode yang digunakan dalam penelitian ini adalah metode deskriptif kualitatif. Metode ini diarahkan untuk mendeskripsikan tindak tutur ilokusi yang digunakan oleh GSD dalam videonya. Sumber data dalam penelitian ini adalah tuturan yang disampaikan oleh GSD dalam video Beropini episode 46. Data dalam penelitian ini adalah tindak tutur ilokusi yang dituturkan oleh subjek penelitian dalam video Beropini episode 46 miliknya.

Data yang diperoleh dianalisis secara deskriptif analitis sesuai masalah yang dikaji dan hasilnya diuraikan menggunakan kata-kata ataupun kalimat, bukan dalam bentuk angka atau mengadakan perhitungan. Peneliti menggunakan metode kualitatif karena data penelitian ini berupa tuturan yang disampaikan oleh GSD, yang data tersebut tidak berupa angka-angka. 
Teknik pengumpulan data yang digunakan dalam penelitian ini adalah: (1) observasi dan (2) pembuatan catatan (note-taking). Observasi yang dimaksud adalah peneliti menonton, menyimak serta mengamati berulang kali video yang dijadikan objek penelitian. Perhatian peneliti fokus pada tindak tutur ilokusi yang dituturkan oleh GSD. Teknik pembuatan catatan digunakan untuk membuat catatan atau transkripsi tuturan yang dituturkan oleh GSD.

Alat dalam pengumpulan data penelitian ini adalah manusia dan perangkat elektronik untuk melihat dan menyaksikan video serta membuat transkripsi tuturan yang dituturkan oleh GSD. Manusia yang dimaksud adalah peneliti itu sendiri, yang dalam peneliti berperanan sebagai instrumen kunci. Langkah yang dilakukan dalam menganalisis data, adalah: (1) peneliti melakukan transkripsi data, (2) peneliti melakukan reduksi data dan klasifikasi data, (3) peneliti memaparkan data (display data) secara analitis sesuai masalah penelitian, dan (4) peneliti menarik kesimpulan secara induktif.

\section{HASIL DAN PEMBAHASAN}

Berdasarkan dari hasil analisis yang telah dilakukan, diperoleh data bahwa tindak tutur ilokusi yang dilakukan oleh GSD terdiri dari tindak tutur ilokusi asertif, tindak tutur ilokusi direktif, dan tindak tutur ilokusi ekspresif. Untuk tindak tutur ilokusi komisif dan tindak tutur ilokusi deklarasi tidak ditemukan dalam penelitian ini.

Tindak tutur ilokusi asertif terdiri dari tindak tutur ilokusi asertif, yang dalam tindak tutur ini penutur mengutarakan pendapat, tindak tutur ilokusi asertif menyatakan informasi, tindak tutur ilokusi asertif menegaskan, dan tindak tutur ilokusi asertif kesimpulan. Tindak tutur ilokusi direktif terdiri dari tindak tutur ilokusi direktif perintah, tindak tutur ilokusi direktif nasihat, dan tindak tutur ilokusi direktif bertanya. Serta tindak tutur ilokusi ekspresif yang terdiri dari tindak tutur ilokusi ekspresif marah dan tindak tutur ilokusi ekspresif sedih. Berikut adalah pembahasan tentang tindak tutur itu.

\section{Tindak Ilokusi Asertif yang Dilakukan oleh GSD}

Pada hasil penelitian ditemukan jenis tindak tutur ilokusi asertif yang terdiri dari tindak tutur ilokusi asertif mengutarakan pendapat, tindak tutur ilokusi asertif menyatakan informasi, tindak tutur ilokusi asertif menegaskan, dan tindak tutur ilokusi asertif kesimpulan.

Contoh tindak tutur ilokusi asertif mengutarakan pendapat yang ditemukan dalam video Beropini milik GSD adalah sebagai berikut.

1. "Gua gak bisa relate kenapa ada seseorang yang bisa sebenci dan se-nasty itu ke orang lain."

2. "Itu menurut gua kenapa kalo kita udah gak suka atau benci sama orang, kita tuh jadi bisa lebih neat picking gitu loh sama apa yang mereka lakuin. Pokoknya apa yang mereka lakuin tuh salah aja di mata kita."

Contoh tindak tutur ilokusi asertif menyatakan informasi yang ditemukan dalam video Beropini milik GSD adalah sebagai berikut.

1. "Sementara, kalo kita benci atau gak suka sama seseorang. Mau orang ini tuh sebenernya berubah, atau sebenernya dia itu udah banyak melakukan hal-hal yang baik 
atau positif. Gak semerta-merta bikin rasa tidak suka kita atau rasa benci kita tuh jadi hilang ke orang ini."

2. "Kalo berdasarkan pyramid of hate, ada lima level kebencian dan macem-macem aksi yang bisa dilakukan gitu berdasarkan kebencian itu."

3. "Apalagi di zaman sosial media sekarang, sangat gampang gitu untuk mencari scapegoat atau mencari kambing hitam dari masalah personal yang kita punya. Mungkin kita ngeliat orang di sosial media ini, dia hidupnya kelihatannya lebih sempurna daripada kita, dia memiliki apa yang kita pinginin sementara kita gak punya. Mungkin kita jadi berpikir, oh ini kambing hitam yang tepat nih buat masalah personal gua."

4. "Di description box gua taro akun-akun psikolog profesional, gua juga naro nomer telfon puskesmas di Jakarta yang buka layanan psikolog."

Contoh tindak tutur yang serupa juga ditemukan dalam penelitian yang dilakukan oleh Hajija, Suryadi, dan Djunaidi (2017), namun dalam konteks yang berbeda. Selain itu, Islam (2017) dalam penelitiannya juga menemukan jenis tindak tutur yang sama. "Alhamdulillah mbak Najwa, setelah bicara itu Presiden Jokowi kemudian mengeluarkan Perpres yang memberikan harga pembelian pemerintah pada harga tiga ribu seratus rupiah". Dari kutipan kalimat di atas merupakan bentuk tutur yang berfungsi untuk menyatakan kebenaran atas apa yang dituturkan, tindak tutur ini termasuk dalam tindak tutur iokusi tepatnya pada ranah asertif. Contoh tindak tutur ilokusi asertif menegaskan yang ditemukan dalam video Beropini milik GSD adalah sebagai berikut.

1. "Jadi membenci orang itu dijadikan semacam defense mechanism atas ketidak sempurnaan diri gitu lho."

Contoh tindak tutur ilokusi asertif kesimpulan yang ditemukan dalam video Beropini milik GSD adalah sebagai berikut.

1. "Nah, yang menurut gua bahaya dari hal ini adalah kita tuh jadi bisa mempengaruhi orang lain untuk benci sama seseorang, padahal orang lain ini belum tentu punya personal experience dimana dia bener-bener dirugikan sama orang itu."

2. "Jadi kalo menurut gua sekarang ini udah gak ada alasan lagi buat kita untuk meremehkan atau menggampangkan isu kesehatan mental kita."

\section{Tindak Ilokusi Direktif oleh GDV}

Pada hasil penelitian ditemukan jenis tindak tutur ilokusi direktif yang terdiri dari tindak tutur ilokusi direktif perintah, tindak tutur ilokusi direktif nasihat, dan tindak tutur ilokusi direktif bertanya.

Contoh tindak tutur ilokusi direktif perintah yang ditemukan dalam video Beropini milik GSD adalah sebagai berikut.

1. "Karena logikanya gini lho, kalo menurut gua nih, kalo lu gak suka sama seseorang gitu, let alone di sosial media. Lu tinggal ignore orang tersebut, lu tinggal mute atau bahkan ngeblok akunnya dia supaya lu gak liat dia lagi. Kelar udah."

2. "Selanjutnya, build compassion. Coba untuk mengerti posisi orang ini. Coba untuk mengenal lebih dekat, seperti kata Sherina. Kalo kita gak bisa ngerti, coba untuk paling 
gak ngehargain. Untuk beberapa kasus yang sebenernya harmless, coba untuk bisa terima perbedaan ini gitu."

Kedua kalimat di atas termasuk dalam tindak tutur ilokusi direktif berupa perintah yang ditandai dengan penggunaan bahasa serta pilihan kata yang digunakan oleh GSD. Dalam kedua kalimat tersebut, Gita secara langsung memberi perintah secara halus dan tidak terkesan memaksa kepada orang-orang yang menonton videonya untuk melakukan apa yang dia sampaikan.

Hal ini serupa dengan penelitian yang dilakukan oleh Ardiyanti (2015). "Saya minta tepuk tangan yang keras untuk menghadirkan sesuatu di ruang ini". Tindak tutur direktif yang diungkapkan oleh Vicky mempunyai maksud meminta penonton untuk memberikan tepuk tangan untuk mengiringi datangnya arwah bantuan dari Ki Kusumo yang akan membantunya meramal.

Persamaan penelitian ini dengan penelitian yang dilakukan oleh Ardiyanti adalah jenis tuturan yang ditemukan dalam kalimat tersebut, yaitu tindak tutur ilokusi direktif yang berupa perintah.

Contoh tindak tutur ilokusi direktif nasihat yang ditemukan dalam video Beropini milik GSD adalah sebagai berikut.

1. "Yang pertama, menurut gua kita tuh harus belajar untuk mencintai diri sendiri."

2. "Self love itu gak cuma bikin kita jadi nyaman sama diri sendiri gitu lho, gak cuma bikin kita nyaman sama keadaan kita, tapi kita juga bisa jadi manusia yang lebih "zen" gitu loh. Kita jadi bisa lebih mudah untuk husnudzon ke orang lain, lebih mudah untuk kasih benefit of the depth ke orang lain. Terus kalo kita melihat orang lain tuh jadi bisa lebih rasional, lebih bisa kritislah, dan lebih bisa untuk sedikit detach sama personal bias kita."

Hasil penelitian yang sama juga ditemukan oleh Aini Nurhayani, dan Hamamah (2020) pada penelitian yang dilakukannya. (6) Masuk seleksi tuh gini, ada beberapa apa namanya eh entry misalnya diseleksi artinya ada penjurian di situ, penjurian artinya bukan meneliti apakah film secara administratif ....jadi seleksi itu berbeda dengan eligible for, masih jauh sih. Dari data (6), menunjukkan penutur ingin memberi nasihat mengenai perbedaan masuk seleksi dan eligible. Dari tuturan "tuh gini" adalah menurut penutur penanda bahwa hal yang seharusnya dilakukan seperti ini.

Contoh tindak tutur ilokusi direktif bertanya yang ditemukan dalam video Beropini milik GSD adalah sebagai berikut.

1. "Terus kalau misalnya lagi ngomongin hal ini tuh tetep ada satu hal yang gua pertanyakan. Kenapa sih bisa sampe orang sebenci itu sama orang lain?"

2. "Sekarang, gimana sih caranya supaya kita bisa paling gak menetralisir sedikit rasa benci yang kita punya terhadap seseorang atau suatu kelompok?"

Hasil penelitian yang sama juga ditemukan oleh Astuti, Widodo, dan Sunoto (2017) dalam penelitian yang dilakukannya, namun dalam konteks yang berbeda.

\section{Tindak Ilokusi Ekspresif oleh GSD}

Pada hasil penelitian ditemukan jenis tindak tutur ilokusi ekspresif yang terdiri dari tindak tutur ilokusi ekspresif marah dan tindak tutur ilokusi ekspresif sedih. 
Contoh tindak tutur ilokusi ekspresif marah yang ditemukan dalam video Beropini milik GSD adalah sebagai berikut.

1. "Tapi, ada satu hal yang bikin gua marah. Fakta bahwa berkali-kali Sulli jadi korban cyber bullying yang mungkin sebenernya juga ngaruh ke kesehatan mentalnya dia."

2. "Jujur, kalo ngomongin soal cyber bullying atau hate speech di sosial media, walaupun gua udah berkali-kali gitu ya jadi korban bullying netizen nih, gua tetep gak bisa ngerti." Hasil penelitian ini sesuai dengan hasil dari penelitian yang dilakukan oleh Novianti (2017). Mogok lagi mogok lagi, servis lagi servis lagi, lama-lama bangkrut juga ni!.huft!! Motor kok bikin sakit kepala, pakai dong New Absolut Revo, teknologi mesin honda terdepan dengan IFT $110 \mathrm{CC}$, irit dan bandel. Pada iklan di atas ditemukan tindak tutur ilokusi ekpresif pada kalimat "Mogok lagi mogok lagi, servis lagi servis lagi, lama-lama bangkrut juga ni! huft!" Contoh tindak tutur ilokusi ekspresif sedih yang ditemukan dalam video Beropini milik GSD adalah sebagai berikut.

1. "Waktu gua pertama kali denger berita tentang Sulli meninggal dunia, jujur gua tuh kaya sedih banget."

\section{SIMPULAN}

Berdasarkan hasil penelitian yang telah dilakukan mengenai jenis tindak tutur ilokusi pada video KKM, Beropini episode 46 di kanal YouTube GSD dapat disimpulkan bahwa tindak tutur yang ditemukan berupa tindak tutur ilokusi asertif, tindak tutur ilokusi direktif, dan tindak tutur ilokusi ekspresif. Sedangkan untuk tindak tutur ilokusi komisif dan tindak tutur ilokusi deklarasi tidak ditemukan pada objek penelitian ini.

Tindak tutur ilokusi asertif yang ditemukan terdiri dari tindak tutur ilokusi asertif mengutarakan pendapat, tindak tutur ilokusi asertif menyatakan informasi, tindak tutur ilokusi asertif menegaskan, dan tindak tutur ilokusi asertif kesimpulan.

Tindak tutur ilokusi direktif yang ditemukan terdiri dari tindak tutur ilokusi direktif perintah, tindak tutur ilokusi direktif nasihat, dan tindak tutur ilokusi direktif bertanya. Tindak tutur ilokusi ekspresif yang ditemukan terdiri dari tindak tutur ilokusi ekspresif marah dan tindak tutur ilokusi ekspresif sedih.

Penelitian ini membahas mengenai tindak tutur ilokusi pada salah satu video Beropini yang ada pada kanal YouTube GSD. Untuk penelitian selanjutnya, peneliti dapat membahas jenis tindak tutur lainnya pada video Beropini di kanal YouTube GSD agar semua jenis tindak tutur dapat ditemukan. Hasil penelitian ini diharapkan dapat digunakan sebagai bahan referensi untuk memahami tindak tutur ilokusi lebih dalam lagi.

\section{DAFTAR PUSTAKA}

Aini, E.N., Nurhayani, I., dan Hamamah. 2020. "Tindak Tutur Joko Anwar yang Mengancam dan Strategi Kesantunan Tidak Langsung terhadap Livi Zheng dalam Acara Q\&A: Belaga "Hollywood" di MetroTV”. Lingua, 17 (1). 
Ardiyanti, R. 2015. "Analsis Jenis Tuturan, Implikatur, dan Kesantunan dalam Wacana Tutur Vicky Prasetyo (Kajian Pragmatik)". Artikel Publikasi. Universitas Muhammadiyah Surakarta.

Astuti, M.P., Widodo, H.S., dan Sunoto. 2017. "Kesantunan Tuturan Direktif dalam Interaksi Pembelajaran di SMA”. Jurnal Pendidikan, 2 (3).

Chaer, A. dan Agustina, L. 1995. Sosiolinguistik: Perkenalan Awal. Jakarta: Rineka Cipta.

Hajija, S., Suryadi, dan Djunaidi, B. 2017. “Tindak Tutur Ilokusi Guru Bahasa Indonesia pada Proses Pembelajaran di Kelas XI IPA 1 SMAN 9 Kota Bengkulu”. Jurnal Ilmiah Korpus, $1(2)$.

Islam, A. 2017. “Tindak Tutur Ilokusi dalam Wawancara Tgh. Muhmmad Zainul Majdi pada Talkshow "Mata Najwa"”. Lingua, 14 (1).

Leech, G. 1993. Prinsip-prinsip Pragmatik. Jakarta: Universitas Indonesia.

Novianti, H. 2017. "Analisis Tindak Tutur Ilokusi Iklan Perdagangan di Radio Harau FM Payakumbuh Periode Pebruari-April 2016". Bahastra, 37 (2).

Rohmadi, M. 2017. Pragmatik: Teori dan Analisis. Surakarta: Yuma Pustaka. 